\title{
Use of Carbonized Fallen Leaves of Jatropha Curcas L. as a Soil Conditioner for Acidic and Undernourished Soil
}

\author{
Takafumi Konaka ${ }^{1}$, Shin Yabuta ${ }^{2}$, Charles Mazereku ${ }^{3}$, Yoshinobu Kawamitsu ${ }^{4}$, \\ Hisashi Tsujimoto ${ }^{1,5}$ (D), Masami Ueno ${ }^{4}$ and Kinya Akashi ${ }^{1,5,6, *}$ \\ 1 United Graduate School of Agricultural Sciences, Tottori University, Tottori 680-8553, Japan; \\ takafumi.konaka@gmail.com (T.K.); tsujim@alrc.tottori-u.ac.jp (H.T.) \\ 2 Faculty of Agriculture, Kagoshima University, Kagoshima 890-8580, Japan; syabuta@agri.kagoshima-u.ac.jp \\ 3 Department of Agricultural Research, Ministry of Agriculture, Private Bag 0033 Gaborone, Botswana; \\ charmazereku@gmail.com \\ 4 Faculty of Agriculture, University of the Ryukyus, Okinawa 903-0213, Japan; \\ kawamitu@agr.u-ryukyu.ac.jp (Y.K.); ruenom@agr.u-ryukyu.ac.jp (M.U.) \\ 5 Arid Land Research Center, Tottori University, Tottori 680-0001, Japan \\ 6 Faculty of Agriculture, Tottori University, Tottori 680-8553, Japan \\ * Correspondence: akashi.kinya@tottori-u.ac.jp; Tel.: +81-857-315352
}

Received: 24 April 2019; Accepted: 6 May 2019; Published: 9 May 2019

check for updates

\begin{abstract}
Jatropha (Jatropha curcas L.) represents a renewable bioenergy source in arid regions, where it is used to produce not only biodiesel from the seed oil, but also various non-oil biomass products, such as fertilizer, from the seed cake following oil extraction from the seeds. Jatropha plants also generate large amounts of fallen leaves during the cold or drought season, but few studies have examined the utilization of this litter biomass. Therefore, in this study, we produced biochar from the fallen leaves of jatropha using a simple and economical carbonizer that was constructed from a standard $200 \mathrm{~L}$ oil drum, which would be suitable for use in rural communities, and evaluated the use of the generated biochar as a soil conditioner for the cultivation of Swiss chard (Beta vulgaris subsp. cicla "Fordhook Giant") as a model vegetable in an acidic and undernourished soil in Botswana. Biochar application improved several growth parameters of Swiss chard, such as the total leaf area. In addition, the dry weights of the harvested shoots were 1.57, 1.88, and 2.32 fold higher in plants grown in soils containing 3\%, 5\%, and 10\% biochar, respectively, compared with non-applied soil, suggesting that the amount of biochar applied to the soil was positively correlated with yield. Together, these observations suggest that jatropha fallen leaf biochar could function as a soil conditioner to enhance crop productivity.
\end{abstract}

Keywords: jatropha; biochar; arid region; acidic undernourished soil; fallen leaves

\section{Introduction}

Jatropha (Jatropha curcas L., Euphorbiaceae) has non-edible oils in its seeds that serve as a feedstock for biodiesel production. Furthermore, since this drought-tolerant species can thrive under a wide range of rainfall regimes, from 200 to over $1500 \mathrm{~mm}$ per annum [1,2], and can grow in poor soils, on eroded land, and on wasteland [3-6], jatropha seed oil also represents a promising feedstock for renewable energy in arid lands [7-9].

The utilization of non-oil biomass products of jatropha has also been evaluated from the perspective of whole-crop biorefineries [10]. Several studies have reported on the production of an organic fertilizer from the seed residues following oil extraction (the seed cake) $[4,11-13]$ and have investigated use of the 
seed cake for bioenergy production, e.g., bio-oil and solid fuel [14-16]. Furthermore, the utilization of jatropha wood biochar as an energy source has been described [17]. The effects of jatropha leaf extracts as a herbal ointment [18], mite [Rhipicephalus (Boophilus) annulatus] repellent [19], and therapeutic agent [20] have been studied, and the positive effects of a biochar amendment made from a mixture of jatropha stems and leaves on jatropha seedling growth have been demonstrated [21]. Recently, production of catalytic biocarbons from jatropha biomass has been demonstrated [22,23].

Jatropha plants growing in the temperate zone are deciduous, losing their leaves in the cold season, so the fallen leaf biomass of this species cannot be neglected when considering whole-crop biorefineries [5,24,25]. A cultivation trial in Patancheru, India, estimated that jatropha trees produce $550 \mathrm{~g}$ of fallen leaves per plant at one year old and $1450 \mathrm{~g}$ at three years old, while the total plant biomass for four-year-old trees was estimated at $6.14 \mathrm{~kg}$ plant ${ }^{-1}$ [26], suggesting that fallen leaves make up a major proportion of the biomass that is produced during jatropha cultivation.

Previous studies have shown that biochar can contribute to agricultural production through improvement of the soil physicochemical properties [21,27,28] and fertilizing effects [29-31], and that the application of biochar derived from wood or organic waste has positive impacts on the growth of many crops, such as rice (Oryza sativa) and maize (Zea mays) [32-34]. Biochar derived from fallen leaves has also been investigated for several species-for example, biochars made from the fallen leaves of ginkgo (Ginkgo biloba) and maple (Acer spp.) trees have been studied as materials for the stabilization of heavy metals in polluted soils $[35,36]$, and the physicochemical properties of fallen leaf biochars made from maple [37] and Eucalyptus saligna [38] have been reported. However, to the best of our knowledge, the use of biochar made from jatropha fallen leaves in the production of edible crops and vegetables has been limited.

In this study, fallen leaves of jatropha derived from a cultivation trial in Botswana $[24,25]$ were pyrolyzed and applied to an acidic and undernourished soil to evaluate the use of jatropha fallen leaves as a feedstock for producing a soil conditioner. In addition, we investigated the performance of a simplified and inexpensive oil-drum carbonizer for the production of jatropha fallen leaf biochar to facilitate the implementation of biochar production in resource-poor villages in rural areas [39-41]. We chose to use Swiss chard (Beta vulgaris subsp. cicla) as a model plant for evaluating the impact of jatropha fallen leaf biochar on crop production because this is commonly grown in Botswana.

\section{Materials and Methods}

\subsection{Production and Analysis of Jatropha Fallen Leaf Biochar}

Fallen leaves of jatropha were collected in July (winter) 2016 from a jatropha cultivation site [24] located approximately $4 \mathrm{~km}$ northeast of the Department of Agricultural Research station in Gaborone, Botswana. The cold-induced defoliation of jatropha in this climatic region has been described previously $[24,25]$. The fallen leaves were dried in the sun and subsequently used for biochar production.

A simplified carbonizer was constructed from a used oil drum of standard $200 \mathrm{~L}$ capacity $(572 \mathrm{~mm}$ diameter, $851 \mathrm{~mm}$ high). The lid of the drum was removed and replaced with a custom-made steel lid that contained a funnel ( $15 \mathrm{~cm}$ high, $7 \mathrm{~cm}$ internal diameter) in the center (Figure 1A). Several holes were then made in the bottom of the drum at approximately $10-15 \mathrm{~cm}$ intervals for ventilation (Figure 1B) and the drum was placed on top of four bricks to ensure air flow from the bottom at the beginning of ignition. 

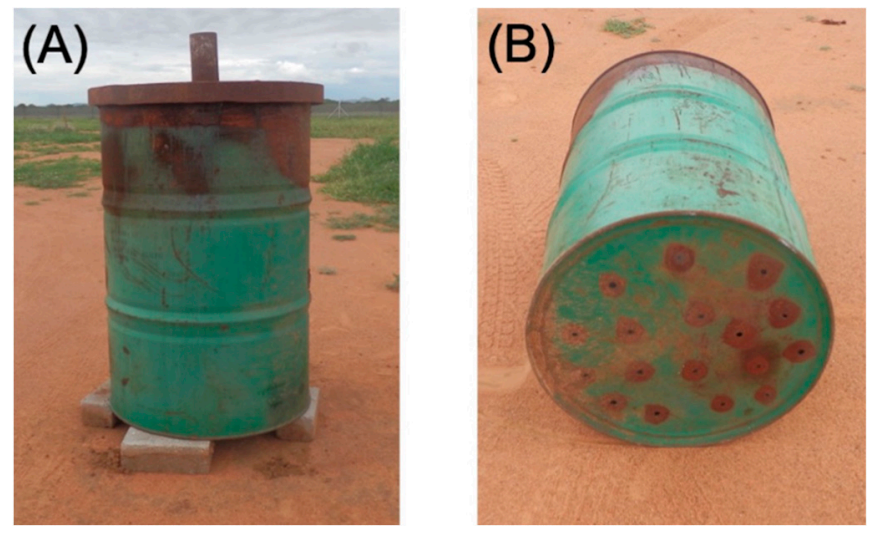

Figure 1. Jatropha fallen leaf biochar production using an oil-drum carbonizer. (A) Side view of the carbonizer. An oil drum was placed on top of bricks and covered with a custom-made lid with a funnel.

(B) Bottom view of the carbonizer. Several ventilation holes were made in the bottom of the oil drum.

Approximately $44 \mathrm{~kg}$ of the jatropha fallen leaves were tightly packed into the drum up to the height of the upper rim by stamping them down with the body weight of an adult. A pilot burner was then provided by placing a burning piece of paper on top of the piled leaves in the drum. After 30 min of burning, the lid was placed on top of the drum and $1 \mathrm{~h}$ later, the top funnel was sealed by a brick and the bottom ventilation was closed by filling the area between the bricks and the bottom of the drum with soil, to suppress combustion inside the drum by blocking the in-flow of the air. The drum was maintained for the next $46.5 \mathrm{~h}$ to promote carbonization, during which time the internal temperature of the carbonizer was continuously measured by three thermocouple sensors with a measurable temperature range of -50 to $800{ }^{\circ} \mathrm{C}$ (TL-13K; Sato Shouji, Tokyo, Japan), which were inserted laterally into the center of the drum through small holes at heights of 15, 45, and $75 \mathrm{~cm}$ from the bottom, and a data logger (Ondotori MCR-4; T\&D Corporation, Nagano, Japan). Then, $48 \mathrm{~h}$ after ignition, the carbonization was stopped by opening the lid manually using refractory gloves, and immediately applying approximately $10 \mathrm{~L}$ of water to the top of the pile. The drum was then left for $6 \mathrm{~h}$, after which time the resulting biochar was spread out on a steel sheet in the open air and left to dry for 10 days, and then mixed extensively with a shovel to ensure homogenization. The surface structure of the biochar was then observed under a VHX-D500 scanning electron microscope (Keyence, Osaka, Japan).

The $\mathrm{pH}$ of the biochar was measured using a Laqua D-51 pH meter (HORIBA Scientific, Kyoto, Japan) at a biochar to water ratio of 1:50 (w/v) and the electrical conductivity (EC) of the biochar was measured with a JENCO VisionPlus meter (JENCO, San Diego, CA, USA). The cation exchange capacity (CEC) of the biochar was measured as described previously [42] with the following modifications. Biochar $(1 \mathrm{~g})$ was placed in a centrifuge tube and $25 \mathrm{~mL}$ of $1 \mathrm{M}$ ammonium acetate was added. The tube was then shaken for $1 \mathrm{~h}$ and centrifuged at $830 \times g$ for $5 \mathrm{~min}$, following which the supernatant was removed and $80 \%$ ethanol was added. The tube was then further shaken for $5 \mathrm{~min}$ and recentrifuged as described above. This ethanol washing procedure was repeated three times. After the final centrifugation, the supernatant was removed and $25 \mathrm{~mL}$ of $10 \%$ sodium chloride was added. The tube was then shaken for $1 \mathrm{~h}$ and centrifuged at $830 \times g$ for $5 \mathrm{~min}$, following which the supernatant was taken into an Erlenmeyer flask and $5 \mathrm{~mL}$ of $18 \%$ formaldehyde aqueous solution and $200 \mu \mathrm{L}$ of $1 \%$ of thymol blue were added. The solution was then titrated with $0.1 \mathrm{~N}$ sodium hydroxide. The CEC value was calculated using a previously described formula [43].

\subsection{Experimental Soil}

To evaluate the effect of biochar on soils that would otherwise be unsuitable for vegetable cultivation, an experimental soil with acidic, $\mathrm{Cu} / \mathrm{Ni}$-rich, and nutrient-poor characteristics [44] was collected from a suburb of Selebi-Phikwe in the central district of Botswana. The organic carbon 
content of the soil was measured using the potassium dichromate method [45] with a UVD 2950 spectrophotometer (LABOMED, Los Angeles, CA, USA).

\subsection{Plant Material and Monitoring of Growth}

Seeds of Swiss chard 'Fordhook Giant' were purchased from Sakata Seed Southern Africa (Lindsay, South Africa). The seeds were initially germinated on a horticulture soil (Potting soil, New Frontiers, Lobatse, Botswana) in a plastic seed tray, where they were grown for 2 weeks until their second true leaves emerged. The seedlings were then transplanted into $2 \mathrm{~L}$ plastic pots filled with the experimental soil supplemented with $0 \%$ (control), 3\%, $5 \%$, or $10 \%(w / w)$ biochar. The plants were provided with $0.5 \mathrm{~L}$ of water every second day.

The length of the longest leaf on each plant was measured weekly using a steel measuring tape. Then, at 44 days after transplantation to the experimental soil, the number of expanded leaves on each plant was counted and the aerial and underground tissues were harvested. The total leaf area was measured with an area meter (LI-3100; LI-COR, Lincoln, NE, USA), following which the whole tissues were dried in an oven at $70^{\circ} \mathrm{C}$ for 2 days and the dry biomass was weighed using an electric balance.

\subsection{Mineral Nutrient Assays}

The unamended soil was decomposed by concentrated sulfuric acid as described previously [46] and their mineral contents were measured by inductively coupled plasma atomic emission spectroscopy (ICP-AES) (SPECTRO CIROS CCD; SPECTRO Analytical Instruments GmbH, Nordrhein-Westfalen, Germany). The biochar and aerial parts of the harvested plants were decomposed as described previously [47] with the following modifications. Dry samples of the biochar $(0.2 \mathrm{~g})$ and aerial parts $(0.1 \mathrm{~g})$ were dissolved in $10 \mathrm{~mL}$ of concentrated nitric acid in a flask and digested on a hot plate for $1 \mathrm{~h}$ at each of $90^{\circ} \mathrm{C}, 140{ }^{\circ} \mathrm{C}$, and $190^{\circ} \mathrm{C}$. The solutions were then evaporated at $220^{\circ} \mathrm{C}$ (biochar) or $240^{\circ} \mathrm{C}$ (aerial parts) until the volume was reduced to approximately $1 \mathrm{~mL}$ and analyzed by ICP-AES as described above. The water-soluble ions $\mathrm{NO}_{3}{ }^{-}$and $\mathrm{NH}_{4}{ }^{+}$were extracted from the soils by mixing $5 \mathrm{~g}$ of soil with $50 \mathrm{~mL}$ of distilled water for $1 \mathrm{~h}$ and were quantified using an RQflex 10 reflectometer (Merck, Darmstadt, Germany).

\subsection{Evaluation of the Water-holding Capacities of the Soils}

After harvest, the experimental soils were spread onto a sheet in a greenhouse with a daily maximum temperature that ranged from approximately 40 to $49^{\circ} \mathrm{C}$ and were dried out for 1 month. Then, $1 \mathrm{~kg}$ of the soils were poured back into the original pots and $500 \mathrm{~mL}$ of water was added. The pots were maintained in the greenhouse and their weights were measured on a daily basis from the day after water addition to estimate the water-holding capacities of the amended and unamended soils.

\section{Results and Discussion}

\subsection{Properties of the Jatropha Fallen Leaf Biochar}

The $200 \mathrm{~L}$ oil-drum carbonizer that was used in this study (Figure 1A,B) was completely filled with dried jatropha leaves and ignited from the top of the piled leaves. Then, $1.5 \mathrm{~h}$ after ignition, both top and bottom ventilation holes were closed, and the biomass inside was subjected to pyrolysis in an oxygen-limited condition. The heating scheme employed in this study is based on the auto-thermal process, in which burning part of the raw biomass material with a controlled air inlet provides the energy necessary for the pyrolysis process [48].

During the heating process, the internal temperature of the drum was monitored at three different heights (Figure 2). In the upper part of the drum (75 $\mathrm{cm}$ from the bottom), the temperature increased immediately after ignition to reach a maximum temperature of $395.1^{\circ} \mathrm{C}$ at $6 \mathrm{~h}$ after ignition (HAI), after which it dropped sharply to $<100^{\circ} \mathrm{C}$ at $10-15$ HAI. In the middle of the drum $(45 \mathrm{~cm}$ from the bottom), the temperature increased from around 1-2 HAI to reach a small peak of $156{ }^{\circ} \mathrm{C}$ at $7 \mathrm{HAI}$. 
The temperature was then maintained between 120 and $200{ }^{\circ} \mathrm{C}$ at $8-42 \mathrm{HAI}$, after which it sharply increased to $370^{\circ} \mathrm{C}$ at $48 \mathrm{HAI}$. In the lower part of the drum $(15 \mathrm{~cm}$ from the bottom), the temperature increased sharply at 6-18 HAI to exceed $400{ }^{\circ} \mathrm{C}$, after which it was maintained at $396-454{ }^{\circ} \mathrm{C}$ until the pyrolysis was extinguished. The maximum temperature in the bottom part was $454^{\circ} \mathrm{C}$ at $46 \mathrm{HAI}$.

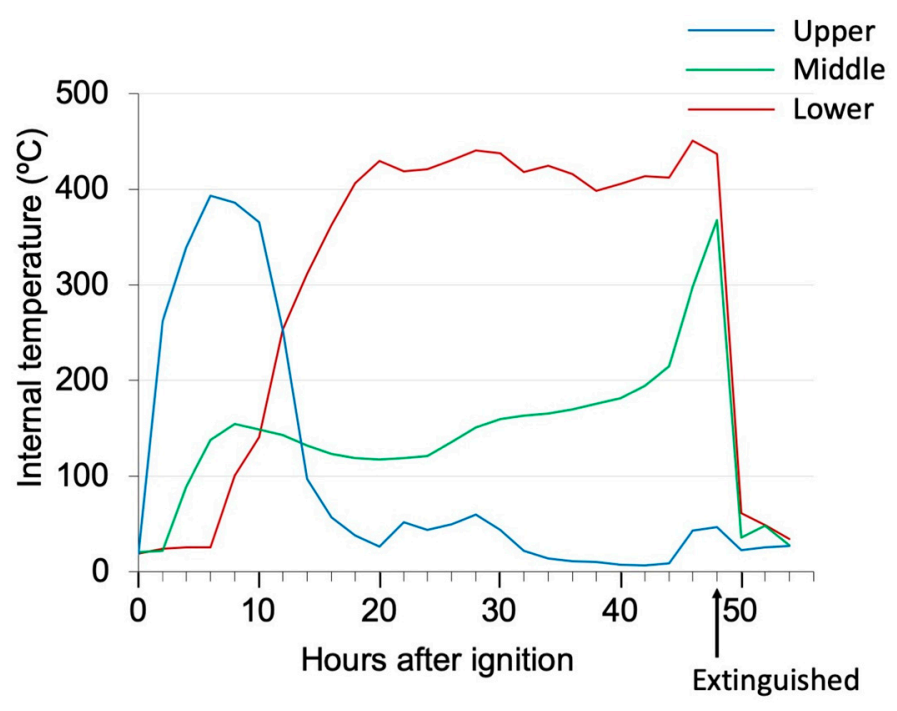

Figure 2. Temporal changes in the internal temperature of the oil-drum carbonizer at three different heights of $15 \mathrm{~cm}$ (lower), $45 \mathrm{~cm}$ (middle), and $75 \mathrm{~cm}$ (upper) from the bottom of the drum. The pyrolysis was terminated at $48 \mathrm{~h}$ after ignition (vertical arrow).

The timing of a sharp decrease in temperature from 365.3 to $26.3^{\circ} \mathrm{C}$ in the upper part of the drum (at 10-20 HAI) appeared to be synchronized with a sharp increase in temperature from 25.6 to $429.5^{\circ} \mathrm{C}$ in the bottom part of the drum (at 6-20 HAI), suggesting that the spatial location of the pyrolysis reaction migrated downward at this time. It is noteworthy that only a modest decreased in temperature from 137.7 to $118.5^{\circ} \mathrm{C}$ was observed in the middle part of the drum at 6-18 HAI. The reason for this behavior is currently unknown, but one possibility is that the heat was transmitted downward via a peripheral route, bypassing the central axis of the drum where the mid-height sensor was located. It is also interesting to note that the temperature in the bottom part of the drum remained high for a prolonged period of time (18-48 HAI). The mechanism driving this phenomenon is also unclear, but it may have been related to a higher density of jatropha leaves occurring at the bottom of the drum due to compression under their own weight, allowing a high temperature to be sustained. The internal temperature profile of the drum suggested that the biomass was subjected to modestly high temperatures in the range of $100-450^{\circ} \mathrm{C}$. This temperature range was similar to those related to the degradation of polymers of hemicellulose, cellulose, and lignin during pyrolysis of plant biomass [22].

When the pyrolysis was terminated by applying water on top of the pile, soot and smoke at a height of approximately $50 \mathrm{~cm}$ evolved from the pile, but vapor explosion did not occur. Since the temperature profile suggested that the pyrolysis products in the drum were heterogeneous, the jatropha biochar was extensively mixed with a shovel for homogenization once the pyrolysis had been completely terminated. The resulting biochar had a mosaic appearance consisting of dark and light brownish fragments and grains of different sizes (Figure 3A), and scanning electron microscopy showed that the surface of subsets of these fragments had a porous structure (Figure 3B), which is a common hallmark of biochar [49]. 

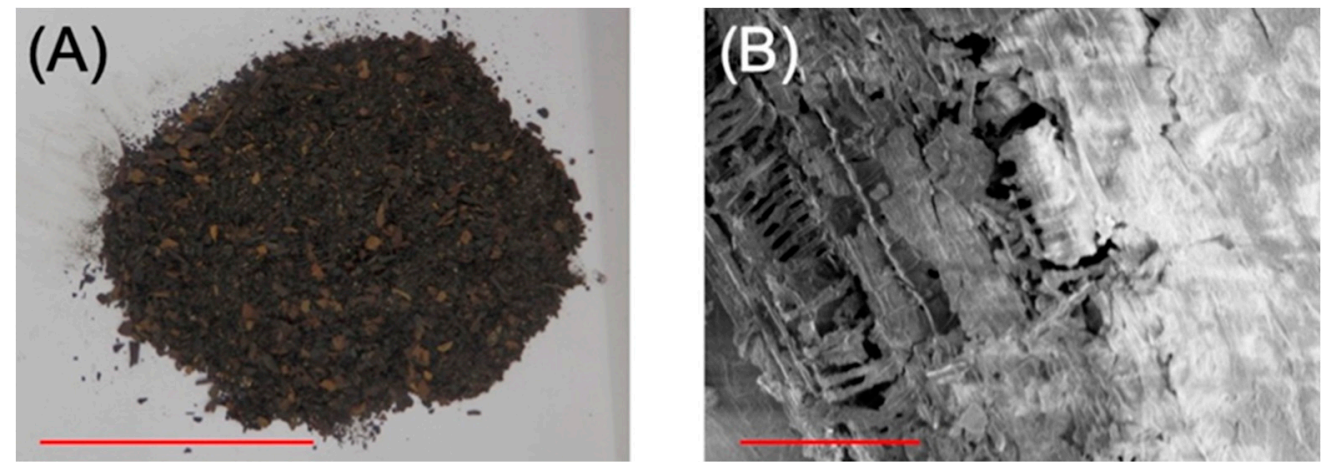

Figure 3. (A) Top view of the jatropha fallen leaf biochar that was produced by the carbonizer. Red scale bar represents $5 \mathrm{~cm}$. (B) Close-up view of the surface of the jatropha fallen leaf biochar observed under an electron microscope. Red scale bar represents $100 \mu \mathrm{m}$.

The jatropha fallen leaf biochar had a pH of $9.84 \pm 0.08$ (Table 1), which was notably higher than that reported by Awasthi et al. [50] for jatropha leaves ( $\mathrm{pH}$ 8.85). The EC of the biochar produced in this study was $575 \pm 108 \mu \mathrm{S} \mathrm{cm}{ }^{-1}$, which was slightly lower than the reported value of $920 \mu \mathrm{S} \mathrm{cm}^{-1}$ for jatropha leaves [50], and the CEC of the biochar was $169 \pm 19 \mathrm{mmol} \mathrm{kg}^{-1}$, which was higher than the reported average values for wheat/barley biochar $\left(103 \mathrm{mmol} \mathrm{kg}^{-1}\right)$ but lower than the average values for corn and rice straw/husk biochar (607 and $212 \mathrm{mmol} \mathrm{kg}^{-1}$, respectively) [51].

Table 1. Properties of the jatropha fallen leaf biochar produced in this study.

\begin{tabular}{cc}
\hline Property & Value $^{1}$ \\
\hline $\mathrm{pH}$ & $9.84 \pm 0.08$ \\
$\mathrm{EC}\left(\mu \mathrm{S} \mathrm{cm}^{-1}\right)$ & $575 \pm 108$ \\
$\mathrm{CEC}\left(\mathrm{cmol} \mathrm{kg}^{-1}\right)$ & $16.9 \pm 1.9$ \\
$\mathrm{Element}^{-1}$ content & $\left(\mathrm{mg} \mathrm{kg}^{-1}\right)$ \\
$\mathrm{Al}$ & $52,900 \pm 700$ \\
$\mathrm{C}$ & $227,000 \pm 12,000$ \\
$\mathrm{Ca}$ & $18,000 \pm 1000$ \\
$\mathrm{Cd}$ & $1.19 \pm 0.03$ \\
$\mathrm{Co}$ & $16.4 \pm 0.2$ \\
$\mathrm{Cr}$ & $29.8 \pm 6.8$ \\
$\mathrm{Cu}$ & $9.39 \pm 0.66$ \\
$\mathrm{Fe}$ & $5080 \pm 340$ \\
$\mathrm{~K}$ & $6220 \pm 530$ \\
$\mathrm{Mg}$ & $741 \pm 62$ \\
$\mathrm{Mn}$ & $617 \pm 46$ \\
$\mathrm{~N}$ & $15,000 \pm 1000$ \\
$\mathrm{Ni}$ & $43.4 \pm 3.4$ \\
$\mathrm{P}$ & $1450 \pm 230$ \\
$\mathrm{~Pb}$ & $18.0 \pm 0.5$ \\
$\mathrm{Sn}$ & $<0.1$ \\
$\mathrm{Ti}$ & $121 \pm 3$ \\
$\mathrm{Zn}$ & $80.1 \pm 6.7$
\end{tabular}

${ }^{1}$ Values are means \pm standard deviations $(n=3)$. EC, electrical conductivity; CEC, cation exchange capacity.

The chemical constituents of biochars are influenced by the feedstock source and the pyrolysis temperature $[29,33]$. The jatropha fallen leaf biochar that was produced in the present study had $\mathrm{P}$ and $\mathrm{K}$ contents of $1450 \pm 230$ and $6220 \pm 530 \mathrm{mg} \mathrm{kg}^{-1}$, respectively (Table 1), which were higher than the reported average values for rice straw/husk biochar (1200 and $700 \mathrm{mg} \mathrm{kg}^{-1}$, respectively) but lower than those for corn biochar (2350 and 19,000 $\mathrm{mg} \mathrm{kg}^{-1}$, respectively) [51]. 
High concentration of $\mathrm{Al}$ was observed in fallen leaf biochar $\left(52,900 \pm 700 \mathrm{mg} \mathrm{kg}^{-1}\right)$. Reasons for this high abundance is currently unknown; one possibility is that jatropha fallen leaves feedstock might be contaminated with Al-rich soil particles during harvest in the field. Alternatively, $\mathrm{Al}$ in fallen leaf biochar might be derived from intrinsic $\mathrm{Al}$ accumulated within jatropha leaves, although absorption and accumulation of $\mathrm{Al}$ in plant leaves are normally inefficient due to its phytotoxicity. The third possibility is that $\mathrm{Al}$ might be derived from leaching from the surface of the used oil drum. Although we extensively washed the inside of drum before usage, this possibility is not totally excluded. Origin of $\mathrm{Al}$ in the fallen leaf biochar should be examined in future studies.

\subsection{Effects of Jatropha Fallen Leaf Biochar on Vegetable Growth in an Acidic and Undernourished Soil}

The experimental soil that was collected from Selebi-Phikwe, Botswana, was highly acidic, with a pH of $3.39 \pm 0.03$ (Table 2), and it is well known that crop growth is generally retarded in acidic soils [52,53]. Furthermore, the experimental soil contained markedly lower contents of the major nutritious elements (e.g., P, $2.67 \pm 0.91 \mathrm{mg} \mathrm{kg}^{-1}$; K, $5.87 \pm 2.76 \mathrm{mg} \mathrm{kg}^{-1}$; Ca, $98.2 \pm 8.5 \mathrm{mg} \mathrm{kg}^{-1}$; and $\mathrm{Mg}, 20.7 \pm 12.0 \mathrm{mg} \mathrm{kg}^{-1}$; Table 2) than typical soils [54], suggesting that it was poor in nutrients. By contrast, the contents of $\mathrm{Cu}\left(772 \pm 8 \mathrm{mg} \mathrm{kg}^{-1}\right)$ and $\mathrm{Ni}\left(249 \pm 2 \mathrm{mg} \mathrm{kg}^{-1}\right)$ were particularly high in the experimental soil (Table 2).

Table 2. Properties of the experimental soil used in this study.

\begin{tabular}{cc}
\hline Property & Value $^{\mathbf{1}}$ \\
\hline $\mathrm{pH}$ & $3.39 \pm 0.03$ \\
Organic carbon (\%) & $0.12 \pm 0.00$ \\
$\mathrm{Nitrogen}^{-}$content & $\left(\mathrm{mg} \mathrm{kg}^{-1}\right)$ \\
$\mathrm{NO}_{3}^{-}$ & $0.12 \pm 0.04$ \\
$\mathrm{NH}_{4}{ }^{+}$ & $0.10 \pm 0.01$ \\
Element content $\left(\mathrm{mg} \mathrm{kg}^{-1}\right)$ \\
$\mathrm{Al}$ & $69,400 \pm 900$ \\
$\mathrm{Ca}$ & $98.2 \pm 8.5$ \\
$\mathrm{Cu}$ & $772 \pm 8$ \\
$\mathrm{Fe}$ & $38,300 \pm 100$ \\
$\mathrm{~K}$ & $5.87 \pm 2.76$ \\
$\mathrm{Mg}$ & $20.7 \pm 12.0$ \\
$\mathrm{Ni}$ & $249 \pm 2$ \\
$\mathrm{P}$ & $2.67 \pm 0.91$ \\
$\mathrm{Zn}$ & $40.4 \pm 0.2$
\end{tabular}

${ }^{1}$ Values are the means \pm standard deviations of three samples for all parameters except $\mathrm{pH}$ and organic carbon, which were derived from two samples.

To examine the effect of jatropha fallen leaf biochar as a soil amendment, the biochar was applied to the experimental soil at rates of 3\%, 5\%, and 10\% $(w / w)$ and the growth of Swiss chard was examined. Swiss chard was chosen as a model crop because it is one of the major vegetables grown in Botswana. Plants that were grown in soil containing $5 \%$ and $10 \%$ biochar had significantly longer leaves than control plants at both 28 days after transplantation (DAT) $(7.33 \pm 0.58 \mathrm{~cm}$ and $9.67 \pm 0.58$ $\mathrm{cm}$, respectively, versus $5.67 \pm 0.58 \mathrm{~cm}$, corresponding to 1.29 and 1.71 fold increases) and 44 DAT at harvest $(9.33 \pm 1.53 \mathrm{~cm}$ and $11.0 \pm 1.00 \mathrm{~cm}$, respectively, versus $6.00 \pm 1.00 \mathrm{~cm}$, corresponding to 1.56 and 1.83 fold increases) (Figure $4 \mathrm{~A}$ ). 
(A)

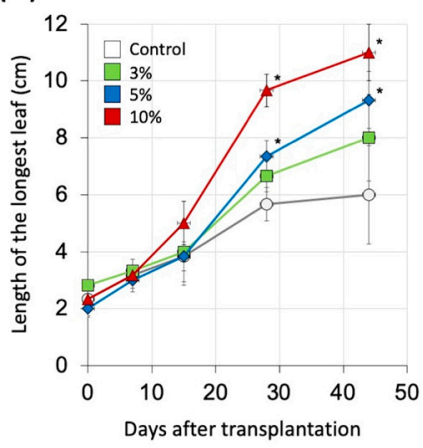

(B)

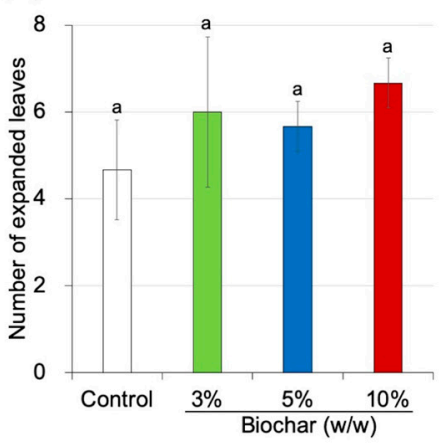

(C)

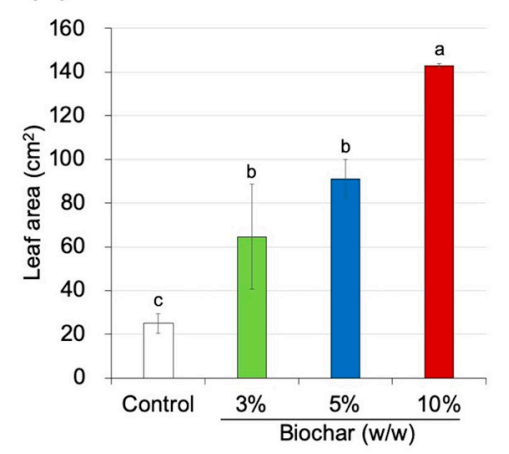

Figure 4. Effects of jatropha fallen leaf biochar application to the experimental soil on the growth of Swiss chard plants. Biochar was applied to the experimental soil at three levels $(3 \%, 5 \%$, and $10 \%(w / w))$ and the growth of Swiss chard plants in the amended soils and unamended control soil was compared. (A) Temporal changes in the length of the longest leaf after transplantation in the biochar-amended soils. (B) Number of expanded leaves and (C) total leaf area per plant at harvest (44 days after transplantation). Values are means \pm standard deviations $(n=3$ plants). Significant differences are indicated by asterisks in $(\mathbf{A})(t$-test, $p<0.05)$ and different letters in $(\mathbf{B}, \mathbf{C})($ Holm's test, $p<0.05)$.

The plants were harvested at $44 \mathrm{DAT}$ and the number of leaves, total leaf area, and dried biomass weight were measured. Plants grown in soils supplemented with $3 \%, 5 \%$, and $10 \%$ biochar had a similar total number of leaves to control plants $(6.00 \pm 1.73,5.67 \pm 0.58$, and $6.67 \pm 0.58$ leaves, respectively, versus $4.67 \pm 1.15$; Figure $4 \mathrm{~B}$ ) but 2.58, 3.64, and 5.71 fold higher leaf areas, respectively, than the control plants (Figure 4C). Furthermore, although biochar treatment had no significant effect on the root dry biomass weight, the shoot and the total dry biomass weights were 1.57, 1.88, and 2.32 fold higher in the 3\%, 5\%, and $10 \%$ biochar-amended soils, respectively, compared with the unamended control soil (Figure 5). These observations indicate that the application of jatropha fallen leaf biochar to the acidic experimental soil improved the growth performance of stalk and leaves of Swiss chard.

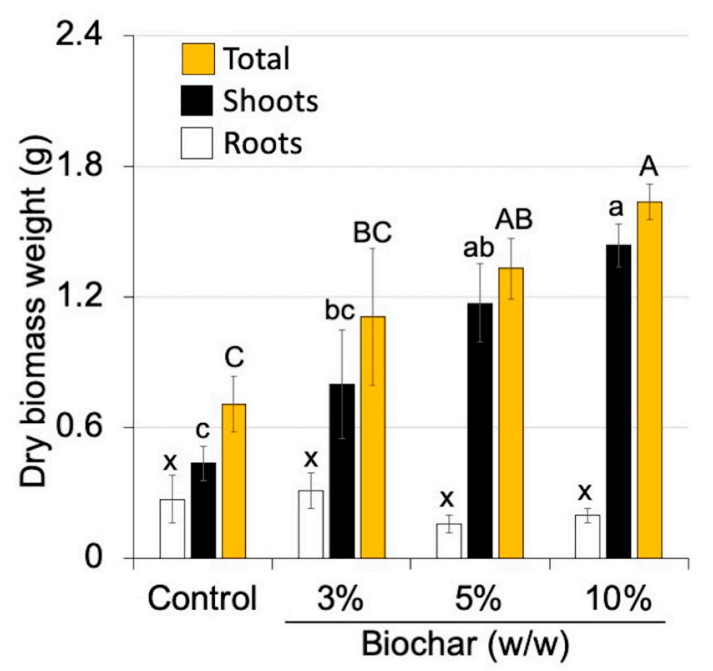

Figure 5. Effects of jatropha fallen leaf biochar application to the experimental soil on the dry biomass weight of Swiss chard plants at harvest (44 days after transplantation). Values are means \pm standard deviations of three independent plants. Sets of bars with different letters are significantly different (Holm's test, $p<0.05$ ).

The improved growth performance of Swiss chard in the biochar-amended experimental soils prompted us to examine the soil conditions and foliar mineral contents of the plants after harvest. 
Biochar application caused the acidic experimental soil $(\mathrm{pH} 4.03 \pm 0.21)$ to become more neutral in a concentration-dependent manner, reaching $\mathrm{pH} 6.62 \pm 0.28$ in the soil containing $10 \%$ biochar (Figure 6A). Furthermore, although the soil $\mathrm{NH}_{4}{ }^{+}$levels were not affected by biochar application, the $5 \%$ and $10 \%$ biochar treatments resulted in a small but significant increase in the $\mathrm{NO}_{3}{ }^{-}$concentration (Figure 6B,C), suggesting that biochar application improved the nitrogen availability. Examination of the foliar mineral levels at harvest showed that the majority of minerals were not significantly affected by the biochar treatment, but potassium exhibited 2.17, 3.76, and 4.00 fold increases following the application of 3\%, 5\%, and 10\% biochar, respectively (Table 3), which may reflect the relatively high potassium content of the jatropha fallen leaf biochar that was used in this study $\left(6220 \pm 530 \mathrm{mg} \mathrm{kg}^{-1}\right.$; Table 1).

(A)

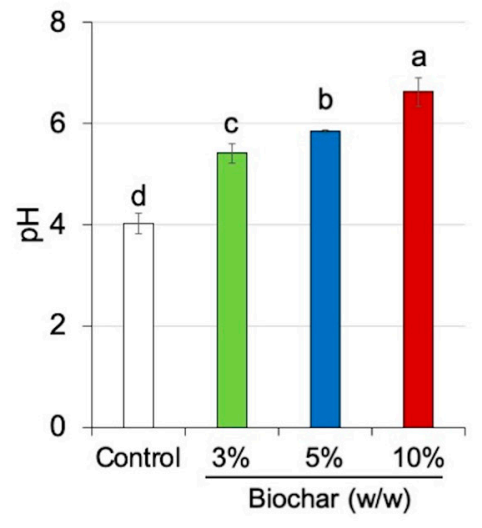

(B)

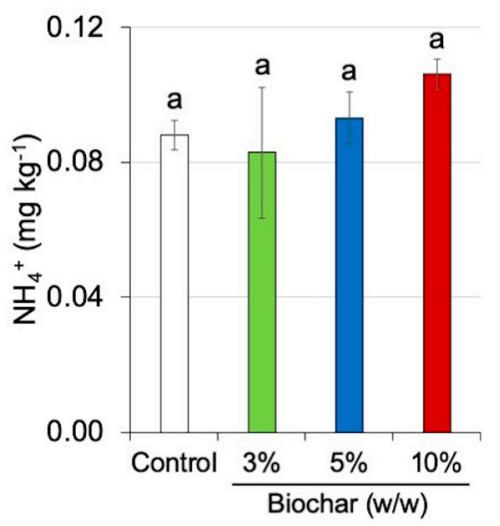

(C)

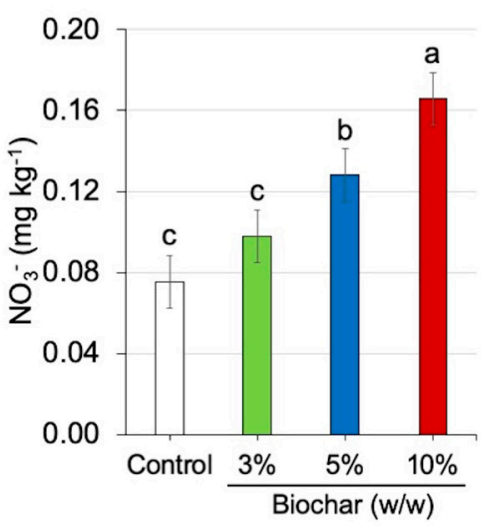

Figure 6. Soil $\mathrm{pH}$ and concentration of major inorganic nutrients in the jatropha biochar-amended soils at the time of harvest. The soil $\mathrm{pH}(\mathbf{A})$ and ammonium ion (B) and nitrate ion (C) contents are shown. Values are means \pm standard deviations ( $n=3$ pots). Bars with different letters are significantly different (Holm's test, $p<0.05)$.

Table 3. Amount of minerals in the aerial parts of the Swiss chard plants.

\begin{tabular}{|c|c|c|c|c|}
\hline \multirow{2}{*}{ Mineral } & \multicolumn{4}{|c|}{ Content (mg plant $\left.{ }^{-1}\right)^{1}$} \\
\hline & Control & 3\% Biochar & $5 \%$ Biochar & $10 \%$ Biochar \\
\hline $\mathrm{Al}$ & $5.35 \pm 1.75^{a}$ & $3.23 \pm 1.41^{a}$ & $3.72 \pm 3.72^{a}$ & $4.53 \pm 2.82^{a}$ \\
\hline $\mathrm{Ca}$ & $7.79 \pm 2.72^{a}$ & $6.87 \pm 1.96^{\mathrm{a}}$ & $5.89 \pm 2.09^{a}$ & $5.98 \pm 1.47^{\mathrm{a}}$ \\
\hline $\mathrm{Cu}$ & $0.01 \pm 0.01^{b}$ & $0.02 \pm 0.00 \mathrm{ab}$ & $0.02 \pm 0.00^{\mathrm{a}}$ & $0.01 \pm 0.00^{a b}$ \\
\hline $\mathrm{Fe}$ & $0.41 \pm 0.20^{\mathrm{a}}$ & $0.19 \pm 0.10^{\mathrm{a}}$ & $0.22 \pm 0.21^{\mathrm{a}}$ & $0.30 \pm 0.18^{a}$ \\
\hline K & $22.0 \pm 0.8^{c}$ & $47.8 \pm 14.5^{b}$ & $82.7 \pm 14.8^{a}$ & $88.1 \pm 9.7^{a}$ \\
\hline $\mathrm{Mg}$ & $0.34 \pm 0.04^{b}$ & $0.48 \pm 0.10^{a b}$ & $0.68 \pm 0.08^{a}$ & $0.68 \pm 0.05^{\mathrm{ab}}$ \\
\hline $\mathrm{Mn}$ & $0.38 \pm 0.10^{b}$ & $0.72 \pm 0.24^{\mathrm{ab}}$ & $0.89 \pm 0.16^{\mathrm{a}}$ & $0.78 \pm 0.07^{a b}$ \\
\hline $\mathrm{Ni}$ & $0.04 \pm 0.02^{b}$ & $0.15 \pm 0.06^{a b}$ & $0.20 \pm 0.06^{\mathrm{a}}$ & $0.04 \pm 0.01^{b}$ \\
\hline $\mathrm{P}$ & $23.1 \pm 1.9^{a}$ & $19.9 \pm 6.5^{\mathrm{a}}$ & $19.8 \pm 5.7^{\mathrm{a}}$ & $21.8 \pm 8.9^{a}$ \\
\hline $\mathrm{Ti}$ & $0.01 \pm 0.01^{\mathrm{a}}$ & $0.00 \pm 0.01^{\mathrm{a}}$ & $0.01 \pm 0.01^{\mathrm{a}}$ & $0.01 \pm 0.01^{a}$ \\
\hline $\mathrm{Zn}$ & $0.27 \pm 0.07^{\mathrm{a}}$ & $0.28 \pm 0.07^{\mathrm{a}}$ & $0.19 \pm 0.03^{a}$ & $0.15 \pm 0.05^{a}$ \\
\hline
\end{tabular}

${ }^{1}$ Values are means \pm standard deviations ( $n=3$ plants). Values with different letters within a row are significantly different (Holm's test, $p<0.05$ ).

\subsection{Effects of Jatropha Fallen Leaf Biochar on the Soil Moisture Content}

The water-holding capacities of the experimental soils supplemented with different amounts of jatropha biochar were evaluated after harvest, by monitoring the pot weight after adding $500 \mathrm{~mL}$ of water to $1 \mathrm{~kg}$ of the dried soils. The weights of the pots containing biochar-applied soils increased in a concentration-dependent manner at each measurement time point (Figure 7). Furthermore, while the weights of the control pots had returned to their pre-watering levels at four days after 
water application, the pots that contained soils supplemented with $3 \%, 5 \%$, and $10 \%$ biochar retained $3.3 \pm 1.2 \mathrm{~g}, 16.3 \pm 1.2 \mathrm{~g}$, and $42.3 \pm 2.1 \mathrm{~g}$ more water, respectively. These observations were consistent with those of previous studies $[21,55,56]$ and suggest that the application of jatropha fallen leaf biochar improved the water-holding capacity of the experimental soil.

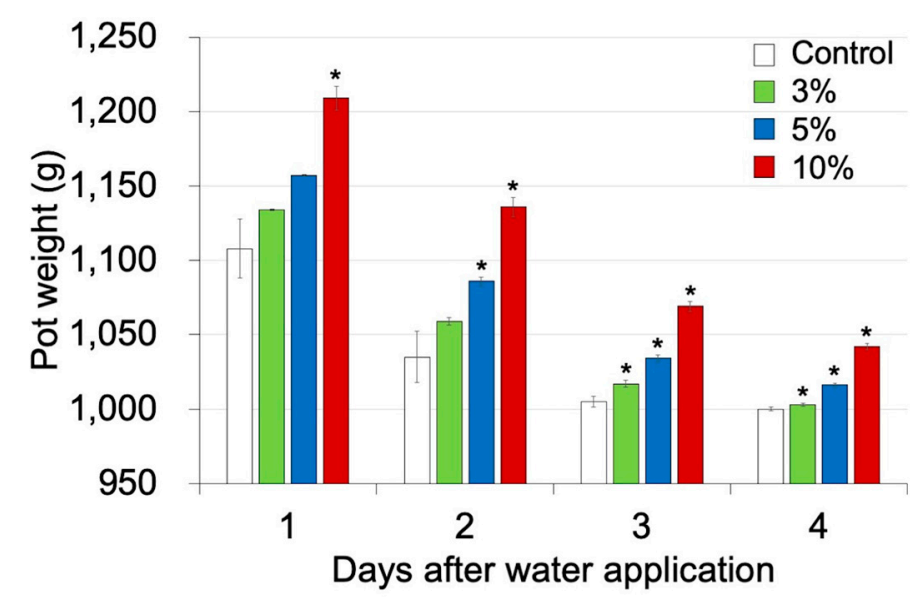

Figure 7. Effect of jatropha fallen leaf biochar application on the moisture contents of the experimental soils. The pot weights were measured daily to estimate the rates of water loss from the potted soils. Values are means \pm standard deviations ( $n=3$ pots per biochar concentration). Asterisks indicate significant differences from the control ( $t$-test, $p<0.05)$.

\section{Conclusions}

This study described the production of jatropha fallen leaves biochar using a simplified oil-drum carbonizer, based on the auto-thermal process in which partial combustion of the biomass provided the energy necessary for the pyrolysis of the remaining biomass. Internal temperature of the drum was maintained in the range of $100-450{ }^{\circ} \mathrm{C}$, and the resultant products had porous surface structure characteristics for biochar. Application of the biochar to an acidic and undernourished soil significantly improved the growth performance of the model vegetable Swiss chard. These findings suggest that jatropha has potential applications not only for producing renewable energy and industrial products, but also as a feedstock for soil conditioner to improve agricultural production.

Author Contributions: T.K., M.U., and K.A. conceived, designed, and performed the experiments. S.Y. and Y.K. prepared experimental materials. M.C. and H.T. contributed to the laboratory works and editing of the manuscript. T.K. analyzed the data and wrote the paper with input from K.A.

Funding: Authors gratefully acknowledge funding of this co-research project under SATREPS program of Japan Science and Technology Agency, Japan International Cooperation Agency and the Government of Botswana, Joint Research Program and the Project Marginal Region Agriculture, the Arid Land Research Center, Tottori University, and the IPDRE Program, Tottori University.

Acknowledgments: The authors thank to the Tottori Agricultural Strategy Division of Tottori Prefecture in Japan for their useful advice on CEC analysis. The authors thank Enago (www.enago.jp) for the English language review. The authors thank for all the participants of the project "Information-Based Optimization of Jatropha Biomass Energy Production in the Frost- and Drought-prone Regions of Botswana" for their counsels.

Conflicts of Interest: The authors declare no conflict of interest. The funding sponsors had no role in the design of this study; in the collection, analyses, or interpretation of data; in the writing of the manuscript, or in the decision to publish the results.

\section{References}

1. Openshaw, K. A review of Jatropha curcas: an oil plant of unfulfilled promise. Biomass Bioenerg. 2000, 19, 1-15. [CrossRef]

2. Quinn, L.D.; Straker, K.C.; Guo, J.; Kim, S.; Thapa, S.; Kling, G.; Lee, D.K.; Voigt, T.B. Stress-tolerant feedstocks for sustainable bioenergy production on marginal land. Bioenerg. Res. 2015, 8, 1081-1100. [CrossRef] 
3. Barua, P.K. Biodiesel from seeds of Jatropha found in Assam, India. Int. J. Energy Inf. Commun. 2011, 2, $53-65$.

4. Montes, J.M.; Melchinger, A.E. Domestication and breeding of Jatropha curcas L. Trends Plant Sci. 2016, 21, 1045-1057. [CrossRef] [PubMed]

5. Pandey, K.K.; Pragya, N.; Sahoo, P.K. Life cycle assessment of small-scale high-input Jatropha biodiesel production in India. Appl. Energy 2011, 88, 4831-4839. [CrossRef]

6. Ye, M.; Li, C.; Francis, G.; Makkar, H.P.S. Current situation and prospects of Jatropha curcas as a multipurpose tree in China. Agrofor. Syst. 2009, 76, 487-497. [CrossRef]

7. Chauhan, B.S.; Kumar, N.; Cho, H.M. A study on the performance and emission of a diesel engine fueled with Jatropha biodiesel oil and its blends. Energy 2012, 37, 616-622. [CrossRef]

8. Jongschaap, R.E.E.; Corré, W.J.; Bindraban, P.S.; Brandenburg, W.A. Claims and Facts on Jatropha Curcas L. Global Jatropha Curcas Evaluation, Breeding and Propagation Programme; Report 158; Plant Research International. B.V.: Laren, The Netherlands, October 2007.

9. Parawira, W. Biodiesel production from Jatropha curcas: A review. Sci. Res. Essays 2010, 5, 1796-1808.

10. Navarro-Pineda, F.S.; Baz-Rodríguez, S.A.; Handler, R.; Sacramento-Rivero, J.C. Advances on the processing of Jatropha curcas towards a whole-crop biorefinery. Renew. Sust. Energy Rev. 2016, 54, 247-269. [CrossRef]

11. Abdul Khalil, H.P.S.; Sri Aprilia, N.A.; Bhat, A.H.; Jawaid, M.; Paridah, M.T.; Rudi, D. A Jatropha biomass as renewable materials for biocomposites and its application. Renew. Sust. Energy Rev. 2013, 22, 667-685. [CrossRef]

12. Srinophakun, P.; Titapiwatanakun, B.; Sooksathan, I.; Punsuvon, V. Prospect of deoiled Jatropha curcas seedcake as fertilizer for vegetables crops-A case study. J. Agric. Sci. 2012, 4, 211-226. [CrossRef]

13. Selanon, O.; Saetae, D.; Suntornsuk, W. Utilization of Jatropha curcas seed cake as a plant growth stimulant. Biocatal. Agric. Biotechnol. 2014, 3, 114-120. [CrossRef]

14. Biradar, C.H.; Subramanian, K.A.; Dastidar, M.G. Production and fuel quality upgradation of pyrolytic bio-oil from Jatropha curcas de-oiled seed cake. Fuel 2014, 119, 81-89. [CrossRef]

15. Chintala, V.; Kumar, S.; Pandey, J.K.; Sharma, A.K.; Kumar, S. Solar thermal pyrolysis of non-edible seeds to biofuels and their feasibility assessment. Energy Convers. Manag. 2017, 153, 482-494. [CrossRef]

16. Kongkasawan, J.; Nam, H.; Capareda, S.C. Jatropha waste meal as an alternative energy source via pressurized pyrolysis: A study on temperature effects. Energy 2016, 113, 631-642. [CrossRef]

17. Kumar, A.; Sharma, S. An evaluation of multipurpose oil seed crop for industrial uses (Jatropha curcas L.): A review. Ind. Crops Prod. 2008, 28, 1-10. [CrossRef]

18. Esimone, C.O.; Nworu, C.S.; Jackson, C.L. Cutaneous wound healing activity of herbal ointment containing the leaf extract of Jatropha curcas L. (Euphorbiaceae). Int. J. Appl. Res. Nat. Prod. 2008, 1, 1-4.

19. Juliet, S.; Ravindran, R.; Ramankutty, S.A.; Gopalan, A.K.K.; Nair, S.N.; Kavillimakkil, A.K.; Bandyopadhyay, A.; Rawat, A.K.S.; Ghosh, S. Jatropha curcas (Linn) leaf extract-A possible alternative for population control of Rhipicephalus (Boophilus) annulatus. Asian Pac. J. Trop. Dis. 2012, 2, 225-229. [CrossRef]

20. Oskoueian, E.; Abdullah, N.; Saad, W.Z.; Omar, A.R.; Ahmad, S.; Kuan, W.B.; Zolkifli, N.A.; Hendra, R.; Ho, Y.W. Antioxidant, anti-inflammatory and anticancer activities of methanolic extracts from Jatropha curcas Linn. J. Med. Plants Res. 2011, 5, 49-57.

21. Ogura, T.; Date, Y.; Maskujane, M.; Coetzee, T.; Akashi, K.; Kikuchi, J. Improvement of physical, chemical, and biological properties of aridisol from Botswana by the incorporation of torrefied biomass. Sci. Rep. 2016, 6, 28011. [CrossRef] [PubMed]

22. Álvarez-Mateos, P.; Alés-Álvarez, F.J.; García-Martín, J.F. Phytoremediation of highly contaminated mining soils by Jatropha curcas L. and production of catalytic carbons from the generated biomass. J. Environ. Manag. 2019, 231, 886-895. [CrossRef]

23. García-Martín, J.F.; Alés-Álvarez, F.J.; Torres-García, M.; Feng, C.H.; Álvarez-Mateos, P. Production of oxygenated fuel additives from residual glycerine using biocatalysts obtained from heavy-metal-contaminated Jatropha curcas L. roots. Energies 2019, 12, 740. [CrossRef]

24. Inafuku-Teramoto, S.; Mazereku, C.; Coetzee, T.; Gwafila, C.; Lekgari, L.A.; Ketumile, D.; Fukuzawa, Y.; Yabuta, S.; Masukujane, M.; George, D.G.M.; et al. Production approaches to establish effective cultivation methods for Jatropha (Jatropha curcas L.) under cold and semi-arid climate conditions. Int. J. Agric. Plant Prod. 2013, 4, 3804-3815. 
25. Ishimoto, Y.; Kgokong, S.; Yabuta, S.; Tominaga, J.; Coetzee, T.; Konaka, T.; Mazereku, C.; Kawamitsu, Y.; Akashi, K. Flowering pattern of biodiesel plant Jatropha in frost- and drought-prone regions of Botswana. Int. J. Green Energy 2017, 14, 908-915. [CrossRef]

26. Wani, S.P.; Chander, G.C.; Sahrawat, K.L.; Rao, C.S.; Raghvendra, G.; Susanna, P.; Pavani, M. Carbon sequestration and land rehabilitation through Jatropha curcas (L.) plantation in degraded lands. Agric. Ecosyst. Environ. 2012, 161, 112-120. [CrossRef]

27. Anders, E.; Watzinger, A.; Rempt, F.; Kitzler, B.; Wimmer, B.; Zehetner, F.; Stahr, K.; Zechmeister-Boltenstern, S.; Soja, G. Biochar affects the structure rather than the total biomass of microbial communities in temperate soils. Agric. Food Sci. 2013, 22, 404-423. [CrossRef]

28. Sohi, S.P.; Krull, E.; Lopez-Capel, E.; Bol, R. A review of biochar and its use and function in soil. Adv. Agron. 2010, 105, 47-82.

29. Atkinson, C.J.; Fitzgerald, J.D.; Hipps, N.A. Potential mechanisms for achieving agricultural benefits from biochar application to temperate soils: A review. Plant Soil 2010, 337, 1-18. [CrossRef]

30. Glaser, B.; Lehmann, J.; Zech, W. Ameliorating physical and chemical properties of highly weathered soils in the tropics with charcoal-A review. Biol. Fertil. Soils 2002, 35, 219-230. [CrossRef]

31. Steiner, C.; Teixeira, W.G.; Lehmann, J.; Nehls, T.; Vasconcelos de Macêdo, J.L.; Blum, W.E.H.; Zech, W. Long term effects of manure, charcoal and mineral fertilization on crop production and fertility on a highly weathered Central Amazonian upland soil. Plant Soil 2007, 291, 275-290. [CrossRef]

32. Asai, H.; Samson, B.K.; Stephan, H.M.; Songyikhangsuthor, K.; Homma, K.; Kiyono, Y.; Inoue, Y.; Shiraiwa, T.; Horie, T. Biochar amendment techniques for upland rice production in Northern Laos 1. Soil physical properties, leaf SPAD and grain yield. Field Crops Res. 2009, 111, 81-84. [CrossRef]

33. Gaskin, J.W.; Steiner, C.; Harris, K.; Das, K.C.; Bibens, B. Effects of low-temperature pyrolysis conditions on biochar for agricultural use. Trans. Am. Soc. Agric. Biol. Eng. 2008, 51, 2061-2069.

34. Major, J.; Rondon, M.; Molina, D.; Riha, S.J.; Lehmann, J. Maize yield and nutrition during 4 years after biochar application to a Colombian savanna oxisol. Plant Soil 2010, 333, 117-128. [CrossRef]

35. Lee, M.E.; Park, J.H.; Chung, J.W. Adsorption of $\mathrm{Pb}(\mathrm{II})$ and $\mathrm{Cu}(\mathrm{II})$ by ginkgo-leaf-deriverd biochar produced under various carbonization temperatures and time. Int. J. Environ. Res. Public Health 2017, 14, 1528. [CrossRef]

36. Nejad, Z.D.; Kim, J.W.; Jung, M.C. Reclamation of arsenic contaminated soils around mining site using solidification/stabilization combined with revegetation. Geosci. J. 2017, 21, 285-396.

37. Mitchell, P.J.; Dalley, T.S.L.; Helleur, R.J. Preliminary laboratory production and characterization of biochars from lignocellulosic municipal waste. J. Anal. Appl. Pyrolysis 2013, 99, 71-78. [CrossRef]

38. Singh, B.; Singh, B.P.; Cowie, A.L. Characterisation and evaluation of biochars for their application as a soil amendment. Aust. J. Soil Res. 2010, 48, 516-525. [CrossRef]

39. Abdel-Fattah, T.M.; Mahmound, M.E.; Ahmed, S.B.; Huff, M.D.; Lee, J.W.; Kumar, S. Biochar from woody biomass for removing metal contaminants and carbon sequestration. J. Ind. Eng. Chem. 2015, 22, $103-109$. [CrossRef]

40. Cobb, A.; Warms, M.; Maurer, E.P.; Chiesa, S. Low-tech coconut shell activated charcoal production. Int. J. Serv. Lean. Eng. 2012, 7, 93-104. [CrossRef]

41. Ishii, T.; Kadoya, K. Effects of charcoal as a soil conditioner on citrus growth and vesicular-arbuscular mycorrhizal development. J. Jpn. Soc. Hort. Sci. 1994, 63, 529-535. [CrossRef]

42. Schollenberger, C.J.; Simon, R.H. Determination of exchange capacity and exchangeable bases in soil ammonium acetate method. Soil Sci. 1945, 59, 13-24. [CrossRef]

43. Borden, D.; Giese, R.F. Baseline studies of the clay minerals society source clays: cation exchange capacity measurements by the ammonia-electrode method. Clay Miner. 2001, 49, 444-445. [CrossRef]

44. Vurayai, R.; Nkoane, B.; Moseki, B.; Chaturvedi, P. Assessment of heavy metal pollution/ contamination in soils east and west Bamangwato Concession Ltd (BCL) Cu/Ni mine smelter in Selebi-Phikwe, Botswana. J. Biol. Environ. Sci. 2015, 7, 111-120.

45. Walkley, A.; Black, I.A. An examination of the Degtjareff method for determining soil organic matter, and a proposed modification of the chromic acid titration method. Soil Sci. 1934, 37, 29-38. [CrossRef]

46. Robinson, B.H.; Leblanc, M.; Petit, D.; Brooks, R.R.; Kirkman, J.H.; Gregg, P.E.H. The potential of Thlaspi caerulescens for phytoremediation of contaminated soils. Plant Soil 1998, 203, 47-56. [CrossRef] 
47. Yamada, M.; Malambane, G.; Yamada, S.; Suharsono, S.; Tsujimoto, H.; Moseki, B.; Akashi, K. Differential physiological responses and tolerance to potentially toxic elements in biodiesel tree Jatropha curcas. Sci. Rep. 2018, 8, 1635. [CrossRef]

48. Boateng, A.A.; Garcia-Perez, M.; Mašek, O.; Brown, R.; del Campo, B. Biochar production technology. In Biochar for Environmental Management, 2nd ed.; Lehmann, J., Joseph, S., Eds.; Routledge: Oxon, UK; New York, NY, USA, 2015; pp. 63-87.

49. Chia, C.H.; Downie, A.; Munroe, P. Characteristics of biochar: Physical and structural properties. In Biochar for Environmental Management, 2nd ed.; Lehmann, J., Joseph, S., Eds.; Routledge: Oxon, UK; New York, NY, USA, 2015; pp. 89-109.

50. Awasthi, M.K.; Li, J.; Kumar, S.; Awasthi, S.K.; Wang, Q.; Chen, H.; Wang, M.; Ren, X.; Zhang, Z. Effects of biochar amendment on bacterial and fungal diversity for co-composting of gelatin industry sludge mixed with organic faction of municipal soil waste. Bioresour. Technol. 2017, 246, 214-223. [CrossRef]

51. Ippolito, J.A.; Spokas, K.A.; Novak, J.M.; Lentz, R.D.; Cantrell, K.B. Biochar elemental composition and factors influencing nutrient retention. In Biochar for Environmental Management, 2nd ed.; Lehmann, J., Joseph, S., Eds.; Routledge: Oxon, UK; New York, NY, USA, 2015; pp. 139-163.

52. Kochian, L.V.; Hoekenga, O.A.; Piñeros, M.A. How do crop plants tolerate acid soils? Mechanisms of aluminum tolerance and phosphorous efficiency. Annu. Rev. Plant Biol. 2004, 55, 459-493. [CrossRef]

53. Marschner, H. Mechanisms of adaptation of plants to acid soils. Plant Soil 1991, 134, 1-20. [CrossRef]

54. Bowen, H.J.M. Environmental Chemistry of the Elements; Academic Press: London, UK; New York, NY, USA, 1979; pp. 60-61.

55. Masiello, C.A.; Dugan, B.; Brewer, C.E.; Spokas, K.A.; Novak, J.M.; Liu, Z.; Sorrenti, G. Biochar effects on soil hydrology. In Biochar for Environmental Management, 2nd ed.; Lehmann, J., Joseph, S., Eds.; Routledge: Oxon, UK; New York, NY, USA; pp. 543-562.

56. Speratti, A.B.; Johnson, M.S.; Sousa, H.M.; Torres, G.N.; Couto, E.G. Impact of different agricultural waste biochars on maize biomass and soil water content in Brazilian Cerrado Arenosol. Agronomy 2017, 7, 49. [CrossRef] 